\section{Safer way to make human stem-like cells revealed}

Shinya Yamanaka of Kyoto University in Japan has refined his method for making human skin cells behave like embryonic stem cells so that it does not use a cancercausing agent.

Late last month, Yamanaka reported making pluripotent cells - cells that can turn into any of the roughly 220 cell types in the body - by using retroviruses to carry four genes into human skin cells (K. Takahashi et al. Cell 131, 861-872; 2007). The four genes reprogrammed the cells into a state similar to that of cells in the early embryo. But one of the genes used to make the cell lines is $c-m y c$, which can cause cancer.

Yamanaka has now shown that he can make these 'induced pluripotent stem cells' in both humans and mice by using just three factors - not including c-myc (M. Nakagawa et al. Nature Biotechnol. doi:10.1038/nbt1374; 2007).

\section{Risk analysis for Boston lab slammed as 'shoddy'}

A US government safety assessment supporting the location of an infectiousdisease lab in Boston was "not sound and credible", says a report issued last week by the US National Research Council.

Construction of the \$178-million Boston University National Emerging Infectious Diseases Laboratory is due to finish in 2008, but one state and one federal lawsuit are challenging its opening. The facility will house research on deadly pathogens such as the Ebola and monkeypox viruses.

The report's criticisms are aimed at a document, released by the US National Institutes of Health (NIH) in July, that evaluated the facility's potential threat to its neighbours. It finds that the worst-case scenarios proposed by the NIH, including an Ebola outbreak caused by an infected lab worker, were not relevant to assessing the true risk. Pathogens with more potential to spread, such as influenza, should have been chosen, the report says. It adds that the NIH assessment suffers from shoddy risk analysis and modelling. The NIH says it will consider the report.

\section{AIDS worker's misconduct ban belatedly comes to light}

Scott Brodie, a former researcher at the University of Washington in Seattle, allegedly committed misconduct when doing AIDS research there in the late 1990s and early 2000 s, and was banned from working for the university, according to The Seattle Times.

The news emerges only now because the newspaper had to win a court case to get a copy of the 2003 report of the investigation. Brodie, under the name John Doe, reportedly sued the university and the newspaper to prevent release of the report.

Brodie left the university in summer 2003 and is currently employed by drug company Schering-Plough, based in Kenilworth, New Jersey. A spokesman for the company says that it has just learned of the investigation.

According to one of the university investigators, geneticist Denny Liggitt, the report was handed to the National Institutes of Health's Office of Research Integrity.

\section{European satellite system is back on the launch pad}

European transport ministers have revived plans for the Galileo satellite-navigation project. The decision comes almost six months after the collapse of a public-private consortium to build the $€ 3$.4-billion (US\$5-billion) network of 30 satellites. Under the new agreement, the European

\section{Endangered species cling on as rulings are overturned}

The US government has revised seven decisions made by a former official who worked on the Endangered Species Act. Julie MacDonald resigned from the Fish and Wildlife Service in May after it emerged that she pressured agency scientists, and solicited advice on decisions from a friend in the online game World of Warcraft.

Preble's meadow jumping mouse (Zapus hudsonius preblei) will not now lose its listing, but will be considered threatened only in Colorado (it is also found in Wyoming)

Twelve endangered species of Hawaiian picture-wing fly will be able to stretch out in 'critical habitats' larger than the 0.4 hectares per species designated for them by MacDonald. And decisions affecting several other species, including the white-tailed prairie dog (pictured) and the arroyo toad, have been deemed flawed. But research needed to revise some of these decisions will be carried out only if funding can be found.

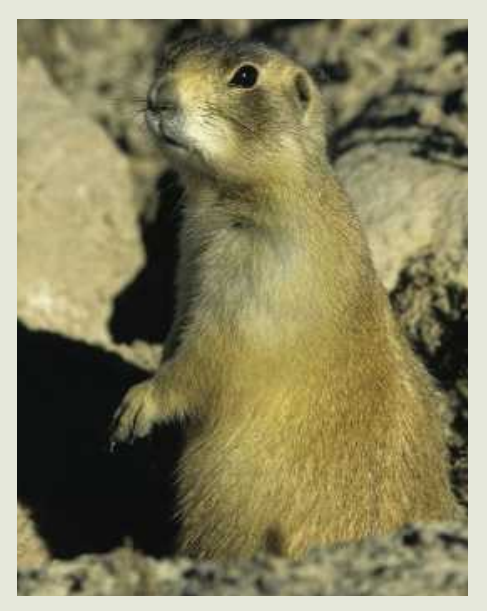

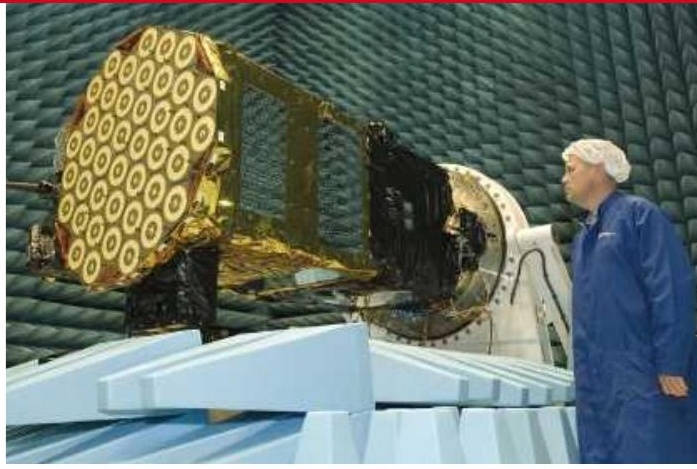

Europe's GIOVE-B is being readied for launch.

Union will provide an additional

$€ 2.4$ billion in unused agricultural funds to finance the system. The decision came despite opposition from Spain, which sought a larger stake in the venture.

Now that funding is confirmed, it will be up to the member states to decide how contracts will be awarded for the project, says Kai-Uwe Schrogl, secretary-general of the European Space Policy Institute in Vienna. "This is now a new game," he says.

So far, only a single test satellite in the Galileo system, GIOVE-A, has been launched. A second, GIOVE-B, has faced repeated delays and is expected to launch in spring next year.

\section{Californian stem-cell directors to be investigated}

California officials may investigate potential conflicts of interest in the state's \$3-billion stem-cell initiative.

State Controller John Chiang has asked for the Fair Political Practices Committee to look into accusations against Robert Klein, the chairman, and John Reed, a board member, of the California Institute for Regenerative Medicine (CIRM) in San Francisco. A public advocacy group has also called for both to resign after it emerged that Reed, on Klein's advice, asked the CIRM to reconsider a grant decision involving a researcher at the Burnham Institute in La Jolla.

Reed is president of the Burnham Institute and intervened after the CIRM decided to rescind a previously awarded $\$ 638,000$ grant to a researcher who was not an on-site, full-time employee of the Burnham Institute.

Klein says he now realizes that Reed should never have written the letter, and that he looks forward to the investigation. "We welcome guidance so that we can learn," he says.

\section{Clarification}

The News story ‘Loopholes in oversight rules revealed' (Nature 450, 590; 2007) referred to a ruling issued by US Department of Energy attorneys in response to a Freedom of Information Act request. We would like to make it clear that the documents that were the subject of that request have not been released. 